\title{
Women in the Customary Village Government System: From Customary Law to Human Rights in Maluku, Indonesia
}

\author{
Mahrita Aprilya Lakburlawal $^{1 *}$, Andi Suriyaman Mustari Pide ${ }^{1}$, Aminuddin Sale ${ }^{2}$, Farida Patittingi ${ }^{2}$ \\ ${ }^{1}$ Faculty of Law, Pattimura University, Maluku, Indonesia \\ ${ }^{2}$ Faculty of Law, Hasanuddin University, South Sulawesi, Indonesia
}

DOI: $10.36348 /$ sijlcj.2021.v04i02.008

| Received: 07.02.2021 | Accepted: 18.02.2021 | Published: 19.02.2021

*Corresponding author: Mahrita Aprilya Lakburlawal

\section{Abstract}

The women are deemed inappropriate to be involved in politics. It certainly detrimental to women because in fact, in terms of women' abilities, they have same abilities as men. The research is a sociological-law research with statutory, conceptual and comparative approaches. The research was conducted in Maluku province, Indonesia. The results show that in the view of Maluku society, women are Limditi Fenreu or glorified or worshiped, but also interpreted as being held. The role of women is sufficient to show their role to be involved in development, although in a small number and not comparable to the presence of men. Even to the village government. In Maluku, representation of women in village government leadership is only around $1.5 \%$ (one-point five percent), this is very small when compared to the total number of villages in Maluku. The lack of representation is influenced by factors of strong patriarchal culture, low willingness of women as a result of their low ability and unavailability of opportunities or opportunities as a result of legal arrangements that do not provide legal certainty. Women in government leadership in Maluku are transformational leadership with a democratic government leadership style.

Keywords: Constitutional Rights, Customary Law, Gender, Human Rights.

Copyright $\odot$ (2021 The Author(s): This is an open-access article distributed under the terms of the Creative Commons Attribution 4.0 International License (CC BY-NC 4.0) which permits unrestricted use, distribution, and reproduction in any medium for non-commercial use provided the original author and source are credited.

\section{INTRODUCTION}

In its existence, women as perfect creatures of God and they are gifted with sufficient potential and abilities as also by men to commit their responsibilities and activities both in general and specific [1]. Women can be understood as inseparable from their physical and psychological context. Women in a psychological or gender context are defined as traits inherent in a person to be feminine [2]. Women are different from men, a universally view which is not limited to mere biological differences. Division of labor by gender separates women and men in the types of work that can and should be done. In the current development, although several fields of work have been undertaken by women, there are still many jobs that are considered

\footnotetext{
${ }^{1}$ Annie Pohlman. 2011. Women and nationalism in Indonesia. Historia: Jurnal Pendidik dan Peneliti Sejarah, 12(1), 13-21.

${ }^{2}$ Niken Savitri, 2008, HAM Perempuan-Kritik Teori Feminis Terhadap KUHP, Rafika Aditama, Bandung, p.
}

inappropriate for women. Teacher, nurse, secretary is a description of ideal positions for women, while men are depicted according to the work of engineers, directors, ministers, or positions related to the world of politics [3]. Politics and political behavior are seen as masculine activities.

The world of politics is synonymous with the world of leadership, while leadership itself tends to be synonymous with power, so that women are deemed inappropriate to be involved in politics. It certainly detrimental to women because in fact, in terms of women' abilities, they have same abilities as men [4]. In the current political sphere, Indonesian women are quite actively involved, but that does not mean that the gap in participation has disappeared. Because there are ${ }^{3}$ Goetz, Anne Marie. 2017. "Gender justice, citizenship
and entitlements." Gender justice, citizenship and
development, 12(4): $15-32$.
${ }^{4}$ Diah Y. Suradiredja and Syafrizaldi, 2019, Perempuan
di Siggasana Lelaki (Atlas pemimpin perempuan
Indonesia), Gramedia, Jakarta, p.37 
Mahrita Aprilya Lakburlawal et al., Sch Int J Law Crime Justice, Feb, 2021; 4(2): 82-88

still gaps in the participation and representation of women in formal political structures, male domination and patriarchal thinking are factors that still cause gaps.

By law, at the international and national levels, Indonesian legal instruments and regulations recognize the principle of equal rights between men and women. In Indonesia, there is still discrimination, injustice and gender inequality at high rates, even for countries at the level of Southeast Asia, Indonesia is in the top three in terms of gender inequality, together with Laos and Cambodia [5]. Although women have the same rights as men, including political rights, but the position of women in a patriarchal society tends to be limited to the domestic area, there is no freedom to make their own choices or decisions regarding their lives. The position of women is always lower than men and they are not involved in decision-making. It happens because men are seen as leaders who make decisions. However, it cannot be denied that many women in historical were able to exercise leadership wisely. History always proves that the power of women' leadership has existed for centuries, although it tends to be blurred in a history writing that is more dominated by men.

Seeing from the long history of women leadership in Nusantara kingdom in the past, it gives this nation the experience that the role of women cannot be denied in caring for the greatness of the archipelago $\left[{ }^{6}\right]$. In the next nation's life, when women are less involved in leadership, they are even considered second-class humans after men, it can indicate a decline. It happens due to the patriarchal culture is also dominant in the customary law of the people of Indonesia, which is an unwritten law that applies also affects position as the subject of customary law. Indonesia as an archipelagic country consisting of thousands of islands inhabited by various ethnic groups, each of which has a uniqueness and diversity, both in religion and in its traditions and cultural customs as well as its own law (customary law), which its existence is recognized and respected constitutionally.

In general, customary villages or areas in Maluku adhere to a form of partnership or a patrilineal kinship system, but there are also customary villages that have a different form of partnership or kinship system namely Matrilineal system. In this society, women are the heirs and men are outside the system so that men are not the heirs. However, even in a society which is in a matrilineal form, women are never given

\footnotetext{
${ }^{5}$ Ristina Yudhanti, 2014, Perempuan Dalam Pusaran Hukum, Thafa Media, Yogyakarta, p. 4

${ }^{6}$ Ryan Sugiarto, Genealogi Ratu Nusantara: Sejarah, Mitos dan Politik Negara Modern, Dalam Jurnal Perempuan (Perempuan Dalam Kabinet) Edition 83 Vol 19 No. 4 November 2014
}

the opportunity to be appointed as kings or the government. Even women in decision making must be based on consideration and represented by their brothers [7].

Later, the development as occur, although in several customary villages or areas in Maluku, women were appointed to be kings or governments based on decisions from Saniri, but the appointment also left problems because they were considered not in accordance with the customary law adhered to by Maluku's people. Whereas in most of the other customary villages, women are not involved in decision making, and are not even allowed to be involved in village meetings other than taking care of consumption, thus they cannot also occupy the position of head of the customary or state village.

Several villages led by women such as Halong and Rumah Tiga in Ambon, Makariki, Kilmury, Rumalatu in Seram island, as well as several villages in other districts such as Lauran in West Southeast Maluku district, Keti Letpei and Emplawas in Southwest Maluku district, Namar and Ohoinol, Southeast Maluku district. Although there are several customary villages led by women, this does not show the realization of the recognition and guarantee of the position of women in adat governance in Maluku. Women in customary governance in Maluku generally do not have the right to hold a king or government position even though these women come from the ruling descent or women who live in customary territories who are subject to a form of matrilineal kinship.

\section{METHOD OF RESEARCH}

The research is a sociological-law research, a study of the position of women in the customary village government system as a social, legal and community phenomenon. It uses statutory, conceptual and comparative approaches. The research was conducted in Maluku province, Indonesia. The sample was determined based on purposive sampling method.

\section{Essence of Women Leadership in Customary Village Government}

Maluku is one of the provinces in the easternregion of the Republic of Indonesia which has a strategic position, due to the position between parts of the western and central regions with Papua in the east, as well as being a link between the southern regions, namely Australia and Timor Leste with the northern regions is North Maluku and Sulawesi.

\footnotetext{
${ }^{7}$ Mahrita A. Lakburlawal, 2014, Kedudukan Suami Dalam Sistem Kekerabatan Masyarakat Adat ditinjau dari Perspektif Hak Asasi Manusia (Studi Pada Desa Letwurung Kecamatan Babar Timur Kabupaten Maluku Barat daya), Jurnal SASI, Vol. 20 (2)
} 
Mahrita Aprilya Lakburlawal et al., Sch Int J Law Crime Justice, Feb, 2021; 4(2): 82-88

Talking about customary governance, the discussion cannot be separated from the constitutional customary law. According to Hilman Hadikusuma in Tolib Setiady, that the rules of customary law governing the structure of indigenous peoples, community forms (alliance), village apparatus, structure and duties of each member of the village apparatus, village assembly, and village assets [8]

Customary institutions are terms that refer to established patterns of human behavior consisting of social interactions and having a structure within a framework of values that are considered relevant. Furthermore, customary institutions based on cultural science are defined as a form of customary organization that is composed relatively permanently of behavior patterns, roles and relationships that are directed and binding on individuals, and have formal authority and customary law sanctions in order to achieve basic needs. Meanwhile, another definition states that a customary institution is a customary community organization formed by a certain customary community, has a certain area and its own assets, and has the right and authority to regulate and manage matters related to customary [9].

In local autonomy, the naming of villages in Maluku was again called Negeri or what was called by another name. Institutionally, customary government in Maluku is called the government, namely village official or Negeri who lead the government. Meanwhile, the government of Negeri is a village government agency of Negeri consisting of the government and heads of Soa. Soa is a genealogical territorial alliance, where each Soa is led by a head of Soa.

In a government administration, today Soa is an area that is part of a Petuanan. In Soa, there are several "rumatau" or "lumatau" a larger genealogical group after the family. "Matarumah" or "Mataluma" which is usually also referred to as "rumatau" or "lumatau" several adjacent Soa in the form of "Henna" or "Amman" led by an Ama (father or lord). At a later stage there arises a larger alliance known as "Uli". Uli is an alliance that is formed or composed of several Hena or Aman. There are 2 (two) types of Uli, namely "uli siwa" which means an alliance of the nine countries

\footnotetext{
${ }^{8}$ Tolib setiady, 2009, Intisari Hukum Adat Indonesia (Dalam Kajian Kepustakaan), Alfabeta, Bandung, p. 377

${ }^{9}$ Wanma, George Frans, Aminuddin Salle, Abrar Saleng, and A. Suryaman Mustari Pide. 2015. "The Existence of Adat Law Community in Indonesian Legal Regulations." Journal of Law, Policy and Globalization, Vol. 39 (1). 126-131
}

and "uli lima" which means an alliance of five countries [10]. Furthermore, there is Saniri Negeri, which usually has 12-15 members consisting of officials, namely Saniri Rajapattih, representatives of Soa (not head of Soa), customary chiefs, landlords, scholars, clerics of spiritual affairs. Its job is to make village regulations, deliberate on important matters, lay out policy lines, and issue regulations.

In principle, it takes a positive view of the position of women that in fact women have the same position as men because they are both God' creatures. In relation to its role in the life of the nation and state in the public sphere, efforts can be made by fulfilling justice based on gender equality so that guarantees for the realization of gender justice is important. However, gender equality does not mean making women superior because they consider themselves special, because gender justice or gender equality is a fair treatment given to both women and men.

This position should be generally accepted and can cover all aspects of life, thus according to the author, the values of Pancasila as the life philosophy of the Indonesian nation can be the right measure to position an equal position between men and women. Because fighting for gender equality/justice does not mean making women superior to men because it creates gender inequality, but fighting for gender equality/justice means placing women as co-workers who are equal to men.

Cooley in his anthropological research states that in kinship there is certain evidence that on Seram island and perhaps in Ambon-Lease before the arrival of outside influences, still adheres to a kinship system arranged based on maternal lines (matrilineal). Then, this basic social pattern underwent a change so that now almost all regions follow a fatherly line (patrilineal). This change may very well be the result of outside influences, especially Islam, which was later strengthened by Christianity and European culture, all of which adhere strictly to a fatherly line in their kinship system and after influencing from outside, Maluku began to adopt a patrilineal system [11].

A community that adheres to the Patrilineal kinship system is the structure of communities drawn according to the father lineage (male line), while the maternal lineage is eliminated. In patrilineal societies, there are those who are pure and impure, pure Patrilineal argue that only men can be descendants,

\footnotetext{
${ }^{10}$ Ibid.

${ }^{11}$ R. Z. Leirissa, G. A. Ohorella, and Djuariah Latukonsina, 1999, Sejarah dan Budaya Maluku, Departemen Pendidikan dan Kebudayaan, Jakarta, p. 121
} 
Mahrita Aprilya Lakburlawal et al., Sch Int J Law Crime Justice, Feb, 2021; 4(2): 82-88

while impure Patrilineal argue that women can be descendants by performing traditional ceremonies so that they are considered men according to the customary perspective [12].

In relation with that, Maluku people as people adheres to a patrilineal kinship system, but there are also people who are bound to a culture of Egalitarianism. In a case in Central Maluku, it is assumed that there is an egalitarian culture, that is certain similarities between men and women are prioritized given the absence of a social stratification system which is assumed to further strengthen the position of men and further weaken the position of women.

In the anthropological vision of the people of Central Maluku, there is a dialectical dualism view between men and women, and it is used as a basic value system for their social life. According to Huliselan, the division can be grouped as follows: (1) Grouping based on power, Patasiwa (men) and Patalima (women); (2) Grouping of population based on territorial, Aman (ama = father) and Hena (ina = mother); (3) The division of the territory of Negeri (village): lau (men) and dara (women); (4) The division of traditional houses (baileu) to the women and men; (5) Classification of customary positions: Kapitan (male), Maweng (customary priest/female), landlord (female), raja (male); (6) Grouping of house eyes (Marga): into groups of men and women during communal traditional ceremonies [13].

In the customary law, the village community in Letwurung, there is a term Timohplol that what women say is true, this is mainly related to customary issues, namely when man and woman is found pregnant with a man but she loves another man as well and when this matter was tried it turned out that this woman called the man she loved (not the man who impregnated her) as the father of her baby, what the woman said was the truth, so it is still the man she loves who must be responsible, not the man who impregnated her.

However, the power of women in Letwurung village is only limited to the private area, in terms of conveying family interests to the public area, it will be the responsibility of the brothers, including in terms of leadership, election of the head of the alliance or the head of the village, all processes tend to be controlled so that until currently there has never been a woman who leads a village.

\footnotetext{
${ }^{12}$ Suriyaman Mustari Pide, Op Cit, pp.60-61

${ }^{13}$ Joseph A. Ufie, Perempuan dan Budaya Maluku, https://oceufi.wordpress.com/category/perempuan-danbudaya-maluku/, accessed on 26 October 2020 at 12. 20 Wita
}

By culture, on the one hand, Maluku women and even women generally receive high respect and appreciation, as daughters, sisters or wives, women are worshiped as jewels, assets or jewelry that must be kept or locked up. Especially with regard to marriage and family customs, in other words, the appreciation tends to be in the domestic or private area only. On the other hand, when it comes to the environment outside the family, women tend to be limited in their movements [14]. Women are considered as weak creatures, who must always be helped, unable to be rational so that they are unable to represent themselves or determine which choices are good and can be made for themselves or for their families, or in social life. The confinement of women is increasingly being carried out in circles of strong patrilineal and patriarchal culture that place men as the holders of power. Leadership is the authority of men, a leader must be men and women outside the system or as objects only for ensure the availability of a successor to perpetuate the system.

In relation to leadership in customary villages or the leader of an indigenous community alliance called Pamerentah by the customary law community in Maluku, as a community that generally adheres to the Patrilineal kinship system, based on the author' research in Maluku, the author finds that in general customary law rules bind members Indigenous community alliances do not limit or prohibit women from being leaders of the association. As long as they come from the lineage of Mata Rumah/clan (Marga) who are entitled to government positions or are called "Mata Rumah", then women have the same rights as men to occupy the position of head of government in a traditional village who has the title of king (in Ambon city, Central Maluku, Eastern Seram, Buru, South Buru and West Seram), the rich/kai (Tual, Southeast Maluku, Aru Islands, Tanimbar and Marna Islands in parts of Southwest Maluku).

Exactly when by Simone de Beauvoir in 1949 in his book Le Deuxieme Sexe. Beauvouir argues that in society (at that time) women were the same as second-class citizens in society, such as a Jew or a Negro. Compared to men, women are second class citizens who unfortunately do not exist more often [15]. This idea later became the forerunner of ideas about gender and even gave birth to the feminist movement. Although there are many feminist currents with different views, there is a common view that unites them, namely the belief that a patriarchal society and legal order is the cause of the injustice of domination and subordination of women to persist. The rule of law

\footnotetext{
${ }^{14}$ Yantje, Liauw and A. Suriyaman M. Pide. 2015.

"Adat Law in Designing of Land Law System." JL Pol'y \& Globalization Vol. 40: 41-46.

${ }^{15}$ Leirissa, et al. loc.cit. h.33 
Mahrita Aprilya Lakburlawal et al., Sch Int J Law Crime Justice, Feb, 2021; 4(2): 82-88

that seems good, neutral and objective often becomes a cover in terms of political and social considerations of society, which of course is not in the interests of women.

Feminists focus emphasizes their struggle on the analysis of the role of law in perpetuating patriarchal hegemony. However, there is an awareness that efforts to reduce patriarchal culture can be pursued through law by seeing and taking the experiences experienced by women.

\section{The Constitutional Rights of Women in the Customary Village Government System}

Constitutional rights are a set of rights agreed upon, regulated and guaranteed in the constitution. Although, the 1945 constitution does not provides any definition of "constitutional rights" [16]. Constitutional rights which include human rights and citizen's rights that have been guaranteed in the Constitution, constitutional rights apply to every Indonesian citizen, both male and female, without exception. This can be seen from the use of the phrase "every person", "all citizens", "every citizen", in the formulation, which shows that every individual of the citizens has constitutional rights without any distinction, either based on ethnicity, religion, political beliefs and gender.

These rights are guaranteed and recognized for every Indonesian citizen, both male and female. Therefore, every female Indonesian citizen has the same constitutional rights as male Indonesian citizens. Thus, women as well as men, Indonesian citizens, have the right to fulfillment and protection of their constitutional rights. There is even an emphasis related to equality and equality, especially regarding the right to be free from threats, discrimination and violence, as confirmed in the 1945 Constitution of the Republic of Indonesia that "everyone has the right to be free from discriminatory treatment on any basis, and is entitled to protection against the discrimination." It can be concluded that, if in practice there are provisions or actions that discriminate against certain citizens, it will not only make it a violation of human rights, but at the same time it becomes a violation of the constitutional rights of citizens, thus it also becomes a violation of the 1945 Constitution of the Republic of Indonesia.

However, it is realized that the fulfillment and protection of the constitutional rights of citizens must be carried out by taking into account the differences in society, because the fulfillment and protection of the constitutional rights of citizens without paying attention to these differences will actually deepen these differences. So that special treatment is needed for certain groups, this understanding aims so that every citizen who has the same ability can obtain the same protection and fulfillment of his constitutional rights. Therefore, the 1945 Constitution guarantees that special treatment, as stated in Article $28 \mathrm{H}$ Paragraph (2) that "everyone has the right to receive special facilities and treatment to obtain equal opportunities and benefits in order to achieve equality."

One of the groups whose condition requires special treatment is women. In their existence, women experience so many problems and issues of gender injustice such as marginalization or the process of marginalization/impoverishment, subordination or subordination of their status as human beings in various fields of life, both in life in the household, community and state, there are government policies, traditional beliefs, habits in culture even in the assumption of science that places women in the second class which is not really important, causing women to lag behind in all fields. Stereotypes or labeling in culture are closely related to duties and roles based on gender or gender, stereotypes in the end give birth to violence or violence that occurs both physically and psychologically which continues to occur in women.

The problems that continue to be experienced by women are what cause women in various studies and arrangements to be classified as vulnerable groups or vulnerable groups, together with children, minority groups and other vulnerable groups, all of which lead to discrimination in the name of gender against women, especially actions that are not the same both before the law in this matter in the laws and in the scope of daily life.

As experienced by women throughout Indonesia, women in Maluku also experience the same problems. There are so many problems experienced by women, in Maluku according to the Data Center for Integrated Services for Women and Children of Maluku province, up to 2019 there were 184 cases of violence against women including cases of rape, cases of sexual harassment, cases of sexual violence, cases of attempted rape, in addition to There are also cases of sexual violence that occur in the context of domestic violence. Even cases of violence against women will continue to increase in 2020 [17].

\footnotetext{
${ }^{16}$ Putri, Andi Wika, Farida Patittingi, and A. Suriyaman Mustari Pide. 2020. "Legal Protection of Indigenous Communities on Cultivation Rights Title in Bulukumba Regency." International Journal of Multicultural and Multireligious Understanding 7, no. 1: 548-555.
}

\footnotetext{
${ }^{17}$ Interview with the administrator of Data Center for Integrated Services for Women and Children of Maluku province, on 11 November 2020
} 
Mahrita Aprilya Lakburlawal et al., Sch Int J Law Crime Justice, Feb, 2021; 4(2): 82-88

The problems of women in Maluku are not only related to violence against women, but also experience discriminatory treatment because they are gender-based in various aspects of life. No exception in customary village governance, especially as a holder of the position of head of a customary village or known as Pamerentah with the title of king. The author finds that in traditional belief leaders are appointed based on lineage so that both men and women can be promoted to become heads of traditional villages. However, in customary practice, boys are prioritized to be appointed kings than girls. Women will be appointed if there are no male candidates who meet the requirements. Even in some districts that held democratic elections, there was very little participation of women because the initial selection process was still carried out according to adat at Soa/Marga.

In Maluku there are structural differences in the customary government system between one region and another, Kei and Aru Islands have similar characteristics, as well as South Buru and Buru, while Ambon, Lease and Seram also have similarities, as the case of Tanimbar and southwest Maluku. The difference is not only related to structure, but also different names or designations. In the customary village governance in Maluku, only a few villages have the power of leadership in the hands of women, and it can be showed in Table-1.

Table-1: Data of women village heads in Maluku, 2020

\begin{tabular}{|l|l|l|l|l|}
\hline No & District/Municipal & Villages & Definitive Village Head & Village Led By Women \\
\hline 1. & Kota Ambon & 30 & 8 & 2 \\
\hline 2. & Maluku Tengah & 186 & 119 & 2 \\
\hline 3. & Seram Bagian Timur & 198 & 82 & 2 \\
\hline 4. & Seram Bagian Barat & 92 & 8 & 1 \\
\hline & Buru & 82 & 12 & - \\
\hline 6. & Buru Selatan & 79 & 79 & 2 \\
\hline 7. & Maluku Tenggara & 190 & 63 & 2 \\
\hline 8. & Kepulauan Tanimbar & 80 & 49 & 1 \\
\hline 9. & Maluku Barat Daya & 117 & 95 & 4 \\
\hline 10. & Kepulauan Aru & 117 & 115 & 2 \\
\hline 11. & Kota Tual & 27 & 6 & - \\
\hline & Total & 1.198 & 636 & 18 \\
\hline
\end{tabular}

Source: Primary data, 2020 (edited)

The table shows that in Maluku women with leadership power at the village level out of a total of 1.198 (one thousand one hundred and ninety eight) villages with a definitive number of village heads, namely 636 (six hundred and thirty six) villages, only 18 of these villages are led by women or around $2.9 \%$ (two point nine percent), from total to definitive villages and only about $1.5 \%$ (one point five percent) of total villages in Maluku. This number indicates an inequality in terms of equality between men and women in village governance. Only a few women can take part to be involved in holding the leadership power of village government, especially customary villages. In fact, as citizens, women have the same rights as men to be involved in becoming government at any level, including village government. It indicate that there are differences in treatment for the existence of women in customary village governance, even though the customary provisions themselves do not limit this, so that in village governance that is motivated by the provisions of customary law that apply in the community, the position of women is equal and equal to the position of men.
In general, in Maluku the appointment of the head of the village government is still bound by the provisions of the applicable customary law that the head of government is appointed or elected based on the descendants of the chair of leadership which is called Mata Rumah Parentah. Regarding this matter are regulated in the regional regulations of each city district, which are sourced from the Maluku Provincial Regulation No. 14 of 2005 concerning Reestablishment of the Country as a Customary Law Community Unit within the Maluku Province, but there are also districts that do not elect or appoint heads village by way of a democratic election. This is what the authors found in this study that although the position of these villages is a village that runs the government according to the provisions of the applicable customary law, and still fulfills all the elements of a customary law community alliance, but changes in regulations have not been bridged by the Provincial and Regency governments. Cities through Regional Regulations related to the designation of customary villages, so that there are villages in Maluku that are very thick with traditional characteristics but are administrative villages. This affects the pattern of appointment and election of village heads, where even though there are Soa/Marga who have the right to rule, this provision cannot run 
Mahrita Aprilya Lakburlawal et al., Sch Int J Law Crime Justice, Feb, 2021; 4(2): 82-88

according to customary provisions but is carried out according to state regulations.

In such villages, women should have a greater chance of being elected as village head, provided that from the initial selection they have been given the same opportunities as men as men to run for office. However, the findings of the authors show that it is still very difficult for women to hold leadership positions in villages in Maluku.

\section{CONCLUSION}

In the view of Maluku society, women have very respected position. Women for the people of Maluku are called Ina/Inai which shows the figure of an embryo site, from which life grows and is maintained. Women are Limditi Fenreu or glorified or worshiped, but also interpreted as being held. The role of women is sufficient to show their role to be involved in development, although in a small number and not comparable to the presence of men. Even to the village government. In Maluku, representation of women in village government leadership is only around $1.5 \%$ (one point five percent), this is very small when compared to the total number of villages in Maluku. The lack of representation is influenced by factors of strong patriarchal culture, low willingness of women as a result of their low ability and unavailability of opportunities or opportunities as a result of legal arrangements that do not provide legal certainty. Women in government leadership in Maluku are transformational leadership with a democratic government leadership style. 